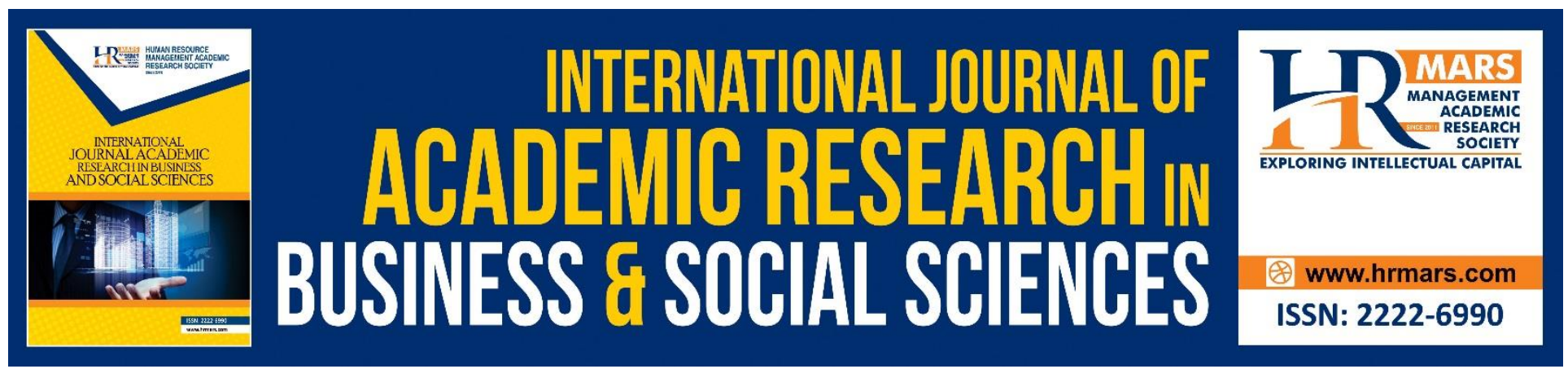

\title{
Sino-Latin America Trade potential and its Influencing
}

\section{Factors}

Ly Aminata

To Link this Article: http://dx.doi.org/10.6007/IJARBSS/v8-i11/4903

DOI: $10.6007 /$ IJARBSS/v8-i11/4903

Received: 06 Oct 2018, Revised: 29 Oct 2018, Accepted: 11 Nov 2018

Published Online: 26 Nov 2018

In-Text Citation: (Aminata, 2018)

To Cite this Article: Aminata, L. (2018). Sino-Latin America Trade potential and its Influencing Factors. International Journal of Academic Research in Business and Social Sciences, 8(11), 300-314.

Copyright: (C) 2018 The Author(s)

Published by Human Resource Management Academic Research Society (www.hrmars.com)

This article is published under the Creative Commons Attribution (CC BY 4.0) license. Anyone may reproduce, distribute, translate and create derivative works of this article (for both commercial and non-commercial purposes), subject to full attribution to the original publication and authors. The full terms of this license may be seen at: http://creativecommons.org/licences/by/4.0/legalcode

Vol. 8, No. 11, 2018, Pg. 300 - 314

Full Terms \& Conditions of access and use can be found at http://hrmars.com/index.php/pages/detail/publication-ethics 


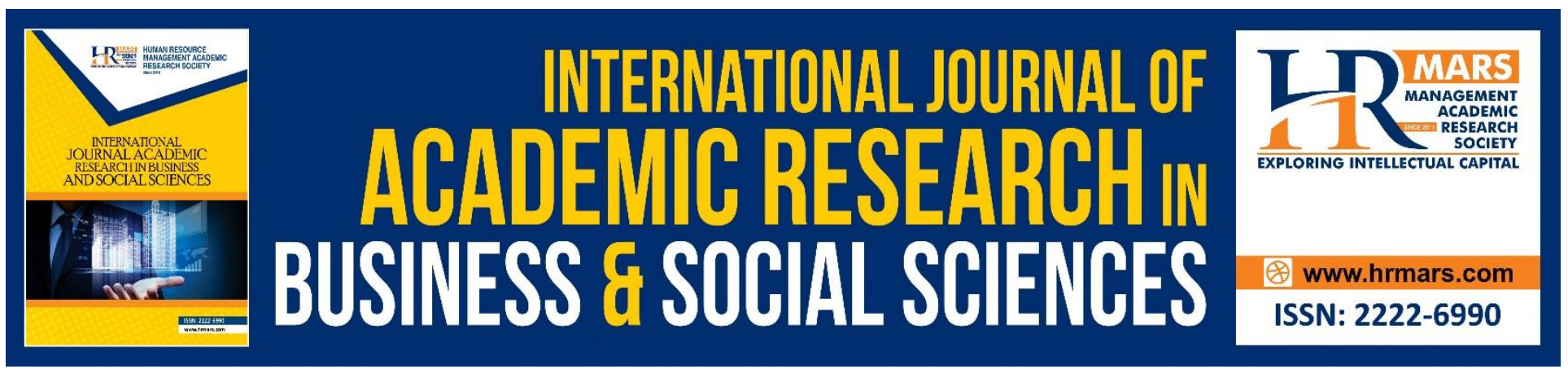

\title{
Sino-Latin America Trade potential and its Influencing Factors
}

\author{
Ly Aminata \\ College of Economics and Management, Nanjing University of Aeronautics and Astronautics, 29 \\ Jiangsu Avenue, Nanjing, China \\ Email: aminataly24@outlook.com
}

\begin{abstract}
We have developed a framework to measure the Sino-Latin America trade potential and its influencing factors by using gravity theory. The objective of the study includes introducing the gravity flow model to measure the bilateral trade flow potential between china and 6-Latin American Countries. The gravity flow model helps to understand the economic challenges that China presents to Latin American's can be uncovered through understanding the bilateral trade policy of Latin American countries toward China. Results shows that China's expenditure on imports has continued to increase at a higher rate than proceeds from exports while during 2006, expenditure on imports amounted to US\$2,557.3 million, which was about US\$ 831,000 more of what was spent in 2004. Other imports include telecommunications, medical and pharmaceutical products. Unlike Asia's increased share of import expenditure, import expenditure share for the African continent significantly reduced from 36.2 percent in 2005 to 25 percent in 2006. Other African trade partners were Republic of South Africa, Egypt, DRC, to name but a few. The study provides a valuable information for policy makers and decision makers.
\end{abstract}

Keywords: Trade Potential, Sino-Latin America, Gravity Model, Influencing Factors

\section{Introduction}

China economy mainly depends on trade and manufacturing sector because trade sector plays a significant role(Dai, Maitra, \& Yu, 2016). Over the past two decades, the China's economy has been introduced as a huge economy, dramatic progress in 'market-oriented' policy reforms has occurred in last two decades especially liberalizing the foreign exchange market and attaining macroeconomic stabilization, notably tight fiscal and monetary policies which help maintain low inflation and strengthen the china's economy. Also the China's macroeconomic stability of recent years has contributed to business confidence and a favorable trade environment all over the world (Breslin \& Nesadurai, 2018). Especially China economic involvement in Latin America is the most substantial 
and dynamic area of involvement in the region. Trade between China and Latin countries increased and the countries benefiting most from this increased engagement were Venezuela, Mexico, Brazil, Nicaragua, Cuba, Argentina, and Chile. This increased involvement is essential because of their vast supply of raw resources that a growing mature economy like China desires insatiably(Eichenauer, Fuchs, \& Brrckner, 2018). The more complex and advanced China's economy becomes, the more such it needs a steady supply of raw materials for advanced manufacturing products and research, which helps continue driving the economy. In China's case, it needs raw materials in a ravenous way, with the world's largest population and government's legitimacy tied to its growth. The relationship between China and all Latin American countries blossomed during the first half of the first decade of the twenty first century see(Denoon, 2017). "China fever" gripped the whole region. Latin American presidents, business executives and journalists discovered China and its rapidly growing impact on the world's economy, which has impact on Latin American countries itself. The principal explanation for this boom in China "fever" was its own economic boom and its deepening worldwide spread (Colloredo-Mansfeld, 2018). Sino-Latin American countries trade and economic relationships are more generally and these relations developed at a spectacular pace in the current decade see (K. C. FUNG, 2012). Latin America benefits from Chinese attention because Chinese investments bring economic prosperity through commodity booms. So it's very important to understand the trade potential between china and Latin American countries. We choose Sino-Latin America trade potential and its influencing factors. The objective of the study includes

(1) Introducing the gravity flow model to measure the bilateral trade flow potential between china and 6-Latin American Countries. The gravity flow model helps to understand the economic challenges that China presents to Latin American's can be uncovered through understanding the bilateral trade policy of Latin American countries toward China. This study will provides in-depth and empirically rich analysis to understanding the determinants bilateral trade flow potential and its influencing factors. (2) To conduct a study on bilateral trade flow, many other factors also influence the trade flows among trade partners, such as the exchange rate, export tax and tariffs, which are controlled by governments. In the prospective of this study, we investigate how Exchange Rate Volatility and Misalignment lower the level of bilateral trade flows between china and 6-Latin American Countries. (3) Provide suggestions to improve the bilateral trade flow between China and 6-latin American countries according to the empirical results.

Rest of the paper sis organized as follows section explain literature and background, section three contain methodology, chapter four explain results section while section five concludes.

\section{Background and Literature Review}

Trade is most powerful tool for industrial development and sustainable economic growth. Trade and economic growth between china and Latin America have been expending exponentially since the dawn of new millennium. China imported a massive amount of raw material from Latin America, which in turned boosted the trade and fast economic growth in the region. China is in the process of redefining its policy toward Latin America in an approach that puts more emphasis on bilateral trade cooperation with individual country in the region. The core objective of this study is to understand the trade relationship between Sino Latin American countries. Since China became a member of the WTO in 2001, its competitiveness in the manufacturing sectors has grown significantly. Undeniably, 
the biggest challenge between china and Latin American trade relations is trade conflict. Therefore, the economic challenges that China presents to Latin American's can be uncovered through understanding the trade relationship between China and Latin American countries. At the same time, many Chinese private firms are looking to invest abroad in a wide range of sectors. This study should help to understand the international trading system, which is largely responsible for economic rise in the region, and to take a more active leadership role in maintaining that system. Further will help to lowering trade and investment barriers, increase economic efficiency, and spur innovation.

The rapid growth of China and its increased integration with the global economy is having both direct and indirect effects on the Latin American region. In the 21st century, as China emerges as a global power and secures a place as the world top exporter, China has taken on enormous importance in Latin America countries, owing in particular to the region's great demand for commodities. A better understanding of the dynamics of the economic relations between China and Latin America is vital in order to identify effective policies that can help countries in the region to deal with the many challenges brought about by China's emergence. It is also important for Chinese policymakers to understand the impacts that China's growth is having in other developing regions and the possible responses to the challenges which China poses. China's influence is also evident through the growth of its investments in Latin America countries, including the construction of infrastructure projects and purchases of businesses in strategic sector and its loans to the region. Now a day's China is the principal trading partner of Brazil. It becomes the leading market for exports from Brazil and Chile and also becomes the second largest one for Argentina, Venezuela, Colombia and Peru. It is very important to understand bilateral trade flow between china and Latin American countries. This study tries to evaluate the determinants of bilateral trade flow and its influencing factors.

The study will analyze what is the Sino-Latin American countries trade potential and its influencing factors, and then put forward suggestions to improve the bilateral trade flow between china and 6latin American countries. The structure is arranged as follows.

Various studies related to international trade flows have been carried out using the Gravity flow model approach in a number of countries. For example, in this research (Nguyen \& Vo, 2017)investigate the determinants of international trade, employing a dataset of bilateral trade and economics characteristics in the ASEAN+3 countries, by using large number of dependent variables that potentially drive international trade and various standard gravity model variables. The results provide some important insights into the determinants of bilateral trade and offer policy implications regarding the promotion of international trade for governments worldwide

(Porojan, 2001) studied determinants of bilateral trade flows using an extended gravity flow model. The variables GDP product, the product derived from per capita GDP of Xinjiang and that of her trade partners and distance among other variables were found to be significantly consistent with the then prevailing trade situation at the time of study.

(Muhammad \& Andrews, 2008) Applied the gravity flow model and panel data for a period of five years $(2000-2004)$ to investigate the impact of origin-specific factors across countries on tourist arrivals in Uganda. The results of the study suggest that over 70 percent of the variation in Ugandan tourist inflows could be explained by real GDP, distance, Ugandan exports by country destination, Ugandan imports by country of origin and exchange rates. Distance was identified as the greatest 
INTERNATIONAL JOURNAL OF ACADEMIC RESEARCH IN BUSINESS AND SOCIAL SCIENCES Vol. 8, No. 11, Nov, 2018, E-ISSN: 2222-6990 @ 2018 HRMARS

factor negatively affecting Uganda's tourist arrivals given that for a unit percent increase in distance from Uganda would lead to a 70 percent decrease in tourist arrivals.

(Alam, Uddin, \& Taufique, 2009)Investigated the determinants of trade flows between various countries. The author applied the augmented gravity flow model on a sample of 146 countries for the five-year sub-periods between 1970 and 2000. The variable included are GDP and distance as well as other variables which included per capita GDP, common official language, common frontier and common currency. Results of the study indicated that GDP, GDP per capita, common frontier, common official language, and common currency have a positive impact on the volume of bilateral trade. On the other hand, the geographical distance factor had a negative effect on the volume of trade. According to (Geda \& Kebret, 2007)who analyzed the determinants of trade using COMESA as a case study, documented that, with the exception of distance, all the standard gravity model variables had plausible and statistically significant coefficients. It was noted that good macroeconomic policies such as financial deepening and infrastructure development were important determinants of bilateral trade in Africa.

The study of (Martínez Zarzoz, Nowak Lehmann, Jaime, \& Nowak-lehmann, 2003) applied the gravity model to assess Mercusor countries and the European Union trade, the model was used to test annual bilateral trade flows on a sample of 19 countries over a period of eight years (1988 - 1996). The basic model variables satisfied the gravity flow model hypothesis which states that, Economic sizes of trading partners positively influenced bilateral trade flows while distance between the economic trading centers of any two trading partners negatively affected bilateral trade flows.

Studies by (De Benedictis \& Vicarelli, 2005), (Baltagi, Egger, \& Pfaffermayr, 2014)and (SantanaGallego, Ledesma-Rodríguez, \& Pérez-Rodríguez, 2016) carried out basing on the gravity flow model framework have tried to predict bilateral trade potentials. In essence, these studies seek to acquire evidence of effects that arise when countries have been integrated in trade so that they can predict the additional bilateral trade flows that might accrue if there is any kind of fostering trade integration between two or more countries. (Martínez Zarzoz et al., 2003)used the estimated coefficients obtained from the gravity flow model to predict Mercosur's export potential to the European Union (EU). Results from the study show that teaming up of Mercosur and Chile provided the highest export potential (approx. 22.6 million) to the EU while Paraguay registered the least export potential (approx. 231,000) to the EU for the entire study period (1988-1996). This implies that Mercosur and Chile have more room to expand their trade to the EU unlike Paraguay. Various researchers used similar methodologies in other fields such as Mohsin et al., (2018).

Also Carrère (2006) used gravity flow to predict Iran's total export trade flow potential to the 76 trade partner countries in 1998. In the analysis, the author categorized the export trade flows into two categories, that is, the developing - industrial countries (DI) and the Intra-developing countries (DD) export trade flows. Findings of the study reveal that of the DI countries export trade flows, United States of America (USA) and Japan had the highest export trade flow potential while Greece, New Zealand and Ireland trailed at the bottom. Among the DD countries export trade flows, Turkey and Pakistan registered the highest export trade flow potential while Argentina, Venezuela, Tunisia among others had very low export trade flow potentials. Most of the countries in this category actually registered zero export trade flow potential. While comparing results of the different gravity 
INTERNATIONAL JOURNAL OF ACADEMIC RESEARCH IN BUSINESS AND SOCIAL SCIENCES Vol. 8, No. 11, Nov, 2018, E-ISSN: 2222-6990 @ 2018 HRMARS

flow model estimators (the traditional static OLS, fixed effects regression and the dynamic specification).

De Benedictis \& Vicarelli (2005) predicted trade potentials, the results indicated that predicted trade potentials vary when one uses the different gravity flow model estimators. Authors further noted that the predicted trade potentials decrease as one uses the traditional static OLS, followed by the fixed effects regression and then the dynamic specification in that order. Although many gravity flow model empirical studies have been conducted on determinants of bilateral trade flows, not much literature review related to analysis of trade performance and Degree of trade integration has been come across.

According to Chen, Yang, \& Liu (2008) who used 34 countries to quantitatively analyze trade performance in 2004, there are two indices, which can appropriately be used to as good measures of trade performance. These are Relative difference and Absolute difference. Their results revealed that Xinjiang had good trading terms with most of her trading partners given that the $R d$ was above zero. Kazakhstan, Pakistan, Germany, Russia and France, among others, were particularly good trading partners with Xinjiang given that their respective $R d$ indices ranged between 0.35 and 0.60 . However, some trading partners like Greece, Iran and Norway had $R d$ indices far below zero (between -0.79 and -0.10$)$ which implied that those partners were not by then cooperating with Xinjiang.

To measure a Korea's degree of trade integration, (Lee \& Kong, 2013)used the ratio of actual trade to potential trade and empirical results from Korea and her 30 major trading partners revealed that China, Japan and Mexico had significant trade barriers. These barriers could have led to the great levels of unexhausted trade potential of about 3,178 (China); 23,163 (Japan) and 2,840 (Mexico) billion US dollars. This assertion was attributed to relatively lower ratios 0.85 (China), 0.67 (Japan) and 0.29 (Mexico) obtained.

\section{Methodology}

The study focuses on China's seven main trade partners Brazil, Chile, Peru, Venezuela, Argentina and Colombia. They were selected basing on the fact that they have been consistent trading partners over the past ten years and have high percentage contribution to total bilateral trade flow with China. This study concentrates on panel data collected over a period of 12 years (2006-2016). This period was selected because the study intends to track the evolution of Uganda's trade partners and to maintain the comparability of the estimated coefficients. The study uses International Financial Statistics (IFS) database of 2006 and 2016 developed by International Monetary Fund (IMF). The IFS provides yearly statistical data classified according to international standards. Other data sources include the annual Statistical.

\section{Model Specification for the Augmented-Gravity Flow Model}

Over the last four decades, the gravity flow model has become a popular formulation for statistical analysis used to predict bilateral trade flows between different geographical entities basing on the economic sizes of the different locations or countries, specifically using GDP measurements(Keum, 2010), (Filippini \& Molini, 2003), (Yayo \& Asefa, 2016). It holds that the attractive force between two objects $i$ and $j$ is a positive function of their respective masses ( $\mathrm{Mi}$ and $\mathrm{Mj}$ ) and a negative function of 
INTERNATIONAL JOURNAL OF ACADEMIC RESEARCH IN BUSINESS AND SOCIAL SCIENCES Vol. 8, No. 11, Nov, 2018, E-ISSN: 2222-6990 @ 2018 HRMARS

the distance (Dij) between them(Camarero, Gómez-Herrera, \& Tamarit, 2018).. This attraction is given by:

$$
F_{i j}=G\left[\frac{M_{i} M_{j}}{D_{i j}{ }^{2}}\right]
$$

Where Fij is the attractive force, Mi and Mj are the masses, Dij is the distance between the two objects and $\mathrm{G}$ is a gravitational constant depending on the units of measurement for mass and force(Ozan Saray, Karagoz, \& Ozan Saray, 2010).

In international economics, the basic gravity flow model states that the size of trade flows between two countries is determined by supply conditions at the origin, demand conditions at the destination and stimulating or restraining forces related to the trade flows between the two countries (Keith, 2003). This can be shown as

$$
F_{i j}=R\left[\frac{M_{i}^{\alpha} M_{j}^{\beta}}{D_{i j}{ }^{\theta}}\right]
$$

Where Fijis the trade flow from origin $i$ to destination $j$, Miis the economic mass (GDP) of exporting country, Mjis the economic mass (GDP) of the other trading partner. D is the distance between the commercial centers of the two countries and $\mathrm{R}$ (Remoteness) replaces the gravitational constant $\mathrm{G}$. Given the multiplicative nature of the model, natural logarithms can be taken to obtain the linear relationship as stated in equation (3).

$$
\ln F_{i j}=\alpha \ln M_{i}+\beta \ln M_{j}-\theta \ln D_{i j}+\rho \ln R_{j}+\varepsilon_{i j}
$$

The augmented-gravity flow model can be expressed as specified below (Foldvari, 2000):

$$
\ln F_{i j}=\alpha \ln M_{i}+\beta \ln M_{j}-\theta \ln D_{i j}+\delta \ln P_{j}+\gamma \ln P_{j}+\rho \ln R_{j}+\varepsilon_{i j} \text { (4) }
$$

Where $\mathrm{Pi}$ and $\mathrm{Pj}$ are the populations of country $\mathrm{i}$ and $\mathrm{j}$, respectively.

The study (Poncet, 2006) used dummy variables with the gravity flow model of trade to investigate the evolution of Yunnan's international trade integration between 1988 and 1999 with a sample of 230 observations. The study focused on assessing the impact of membership to the Great Mekong Sub-region (GMS). Results showed that a large degree of trade integration existed between Yunnan and Myanmar for both imports and exports. However, Yunnan depicted a negative degree of trade integration with Thailand and Vietnam implying no existence of good trading terms. The expansion in economic relations was due to the improved political relations because intergovernmental agreements facilitate economic relations and the exuberance of the economic boom outpaced the improvement in political relations see. From a Chinese viewpoint interests have been focused mostly on relations with dominant countries in the developed global North, as well as on relations with its regional neighbors; while there has been barely any interest in Latin American countries and Africa see. However, China's economic interest in developing countries has grown with its growing industrialization and internationalization. For example, during the last 15-20 years China's economic presence and its interest in Africa continent has grown substantially and also gaining much interest from the academic community see (Buckley et al., 2010).

China has also gradually become important for Latin American countries in the same period and raising the interest of academics, politicians and business executives in Latin America in Sino-Latin America relations. These interests took off particularly, when China's becomes the member of World Trade Organization in 2014 and although a country like Brazil already celebrated a strategic partnership with China in 1993 see(WTO, 2015). While China's trade volume with Asian countries is 
INTERNATIONAL JOURNAL OF ACADEMIC RESEARCH IN BUSINESS AND SOCIAL SCIENCES

Vol. 8, No. 11, Nov, 2018, E-ISSN: 2222-6990 @ 2018 HRMARS

still larger than its trade with Latin America countries. However the People's Republic of China has already trading relations with Brazil, Chile and Peru. According to the Ministry of Development and Foreign Trade, in 2013 the Brazil's bilateral trade with China grew by $10 \%$ and to reach US $\$ 83,300 \mathrm{~m}$ see (Nica, 2013).

\section{Results}

China is an industrialized and agricultural country, its exports are mostly related to industrial and agricultural products. However, other economic sectors such as mineral resources, agriculture, and tourism have also contributed to the country's exports. (Hennig \& Harlan, 2018). In general, China's total exports have been changing over the past decade as presented in Table 1. For example, exports of china progressively increased from about $\$ 16.695$ billion to about $\$ 68.78$ billion between 2006 and 2017 , and then fell sharply to $\$ 68.8$ million in the next five years. At the beginning of 2006, most of the exported products were shipped to Brazil, Chile and Peru. From the end of 2007 to the middle of 2009, China's exports to Venezuela, Argentina and Colombia fell especially, while trade with Mexico began to prosper. This booming trade has greatly boosted China's exports in Latin America alone in 2013, totaling more than $\$ 35.595$ billion. Since then, as many other trading partners have gradually become involved in trade with China, total exports have been between $\$ 7,380$ and $\$ 358.95$ billion annually. For example, export trade with Chile began to flourish only in early 2006.

Since 2009, China has become the world's largest exporter of goods. The official estimate of China's annual export value is 1.904 trillion US dollars. The country took over from the United States in 2013 and became the world's largest trading nation (Munir \& Javed, 2018). China accounts for a large proportion of global natural resources such as coal, aluminum, iron ore and copper(Wellmer et al., 2019). For example, some commodities such as coal consume much more domestically, and consumption is much higher than imports. China is the world's largest cotton textile producer, and the textile industry is also the largest in terms of overall production and exports.

Table 1 China's Exports to Latin American Countries (US Dollar Thousands) 2000-2017

\begin{tabular}{llllllll}
\hline Years & Brazil & Chile & Peru & Venezuela & Argentina & Colombia & China total exports \\
\hline 2006 & 7380106 & 3109030 & 1008535 & 1698021 & 2003896 & 1496274 & 16695862 \\
2007 & 11398472 & 4432221 & 1683201 & 2838505 & 3581131 & 2270851 & 26204381 \\
2008 & 18807457 & 6186804 & 2774372 & 3365981 & 5054733 & 2987931 & 39177278 \\
2009 & 14118518 & 4928470 & 2098874 & 2811265 & 3482893 & 2396433 & 29836453 \\
2010 & 24460652 & 8024930 & 3549668 & 3648587 & 6115764 & 3819950 & 49619551 \\
2011 & 31836677 & 10816758 & 4653277 & 6521892 & 8502556 & 5838843 & 68170003 \\
2012 & 33413633 & 12600992 & 5332544 & 9304091 & 7869366 & 6228774 & 74749400 \\
2013 & 35895471 & 13105469 & 6188838 & 6064501 & 8750430 & 6826037 & 76830746 \\
2014 & 34890134 & 13017501 & 6100848 & 5657421 & 7679829 & 8043334 & 75389067 \\
2015 & 27412225 & 13290323 & 6354974 & 5315772 & 8805106 & 7580793 & 68759193 \\
2016 & 21976153 & 12802834 & 5989777 & 2518913 & 7200838 & 6752373 & 57240888 \\
2017 & 29078324 & 14459966 & 6981392 & 1751130 & 9067643 & 7443100 & 68781555 \\
\hline
\end{tabular}


China's exports have grown steadily over the past decade, with the exception of the 2009 financial crisis and the global economic downturn that has led to a slowdown in global trade. In addition to being the most populous country, China has become the world's largest manufacturing economy and the largest exporter (Kingstone, 2018).

Since the economic reforms of 1978, textiles and clothing have been one of the earliest products produced and traded in China. Today, China has become the world's largest textile producer and exporter. The Chinese textile industry income was approximately $\$ 526$ billion in 2013. As of 2012, China approximately global textile exports accounted for $33.4 \%$, followed by the India and European Union accounting for $5.3 \%$ and $24.3 \%$ respectively (Schütz \& Palan, 2015). In the past few years, China has been trying to upgrade global value chains by shifting to high end exports such as electronics and power equipment. While, China was the top ranked global electronic components and integrated circuits exporter in 2015 (Gilboy, 2016).

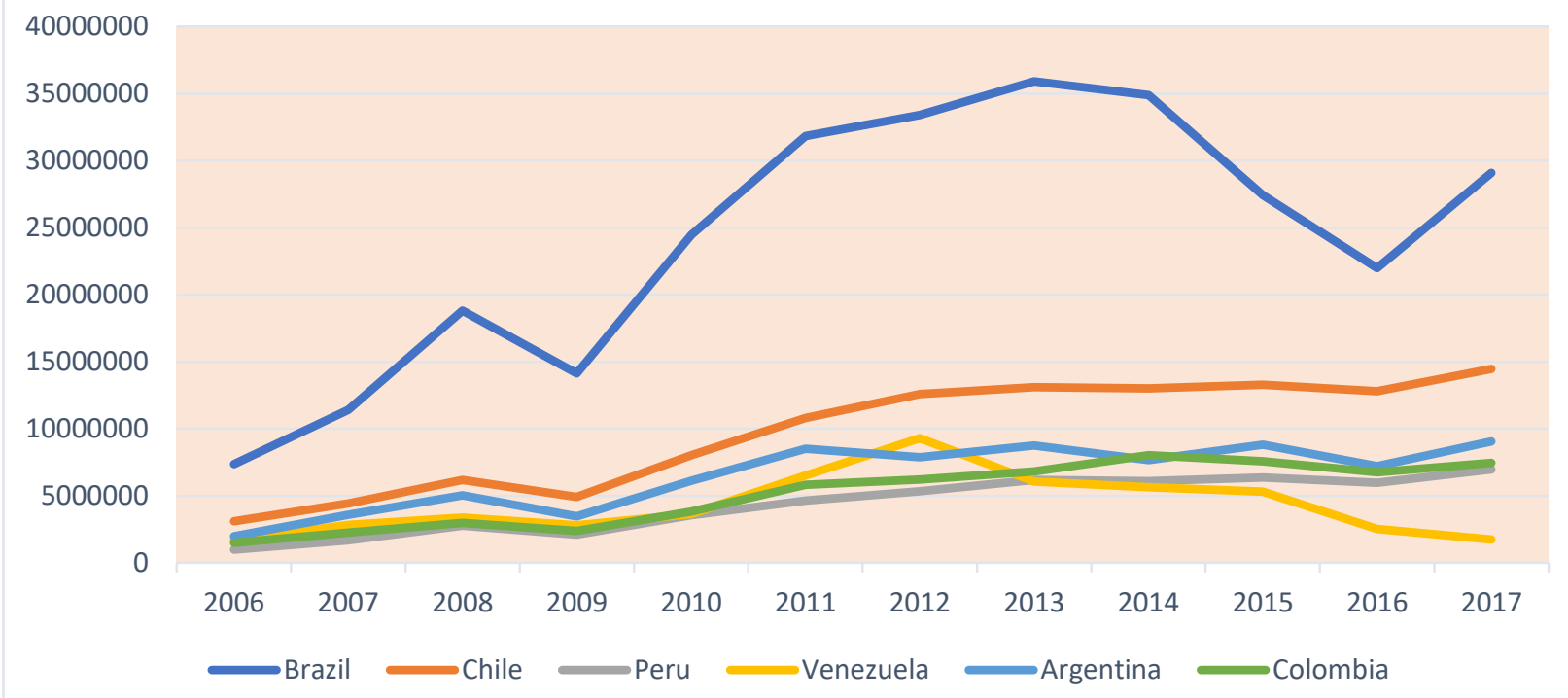

Figure 1 china exports to Latin American Countries (US Dollar thousand) 2000-2017

According to Chinese Trade ministry Counselor "Yu Zhong" the value of trade increased to \$241.5 billion in 2014. Between 2000 and 2009, trade between China and Latin America increased by 1,200\%, from $\$ 1$ billion to $\$ 130$ billion. The United States was only a larger trader then china and the top five nations in the Latin American countries in trade were Brazil, Chile, Mexico, Argentina and Venezuela (Shapiro, Vecino, \& Li, 2018).

Latin America's exports more than $7 \%$ were to China in 2009. It is mainly composed of raw materials and commodities such as oil, soybeans, copper and iron ore.(Teng, 2015). China is the largest export market for Brazil, Peru and Chile, it is the second largest export market for Venezuela, Argentina and Colombia. As shown in Figure (2) $90 \%$ of exports contributed four countries such as $41 \%$ in Brazil, 23.1\% in Chile, 15.9\% in Argentina, and 9.3\% in Peru. The increase in demand in China is also believed to increase the price of goods exported by Latin America. As far as Brazil is concerned, the rise of the new middle class is even considered to be due to China's commodity demand. Conversely, due to free trade agreements with China a large part of the exports Costa Rican, El Salvador and Mexico are high tech manufactured good (Murakami \& Hernández, 2018). In 2009, China's 5\% of its exports went 
INTERNATIONAL JOURNAL OF ACADEMIC RESEARCH IN BUSINESS AND SOCIAL SCIENCES Vol. 8, No. 11, Nov, 2018, E-ISSN: 2222-6990 @ 2018 HRMARS

to Latin America, mainly including manufactured and industrial goods and due to low cost Chinese goods are very popular in this region. Also for the new middle class Chinese manufacturers are also trying to build their own brand. Moreover in Latin America region china is opening doors for investment and in Brazil and Argentina investing in power plants and repairing a railway respectively(Wise, Myers, \& Myers, 2016). According to the Fitch Rating Report("Fitch Home," n.d.), 92\% of Latin American exports to China in 2010 were commodities. The report pointed out that this impact is uneven, but overall Latin America benefits from China's relationship with China's accelerated growth, rising commodity prices, improved government financial conditions and increased investment. Therefore many of the environmental impacts involving Chinese companies in Latin America's extractive industries and agriculture have increased dramatically, including pollution, habitat destruction, deforestation and increased fossil fuel emissions (Allende, 2016).

In addition, Latin American manufacturers in international and domestic market face increasing competition from China. There have protests in some countries in contrast to the raising inflow of local Chinese businesses, Chinese manufactured goods and perceived reduction of manufacturing jobs to China (Barton \& Rehner, 2018). The Future of Latin America and China found that 92\% manufacturing exports from Latin American were in sectors. Where China was increasing its market share while Latin America was decreasing its share, or where both China and Latin America, where increasing their shares but Latin America at a slower rate. Several experts have even argued that the long-term outlooks for Latin American manufacturing are poor and other sources for growth and trade such as services should be sought (Castro, 2018).

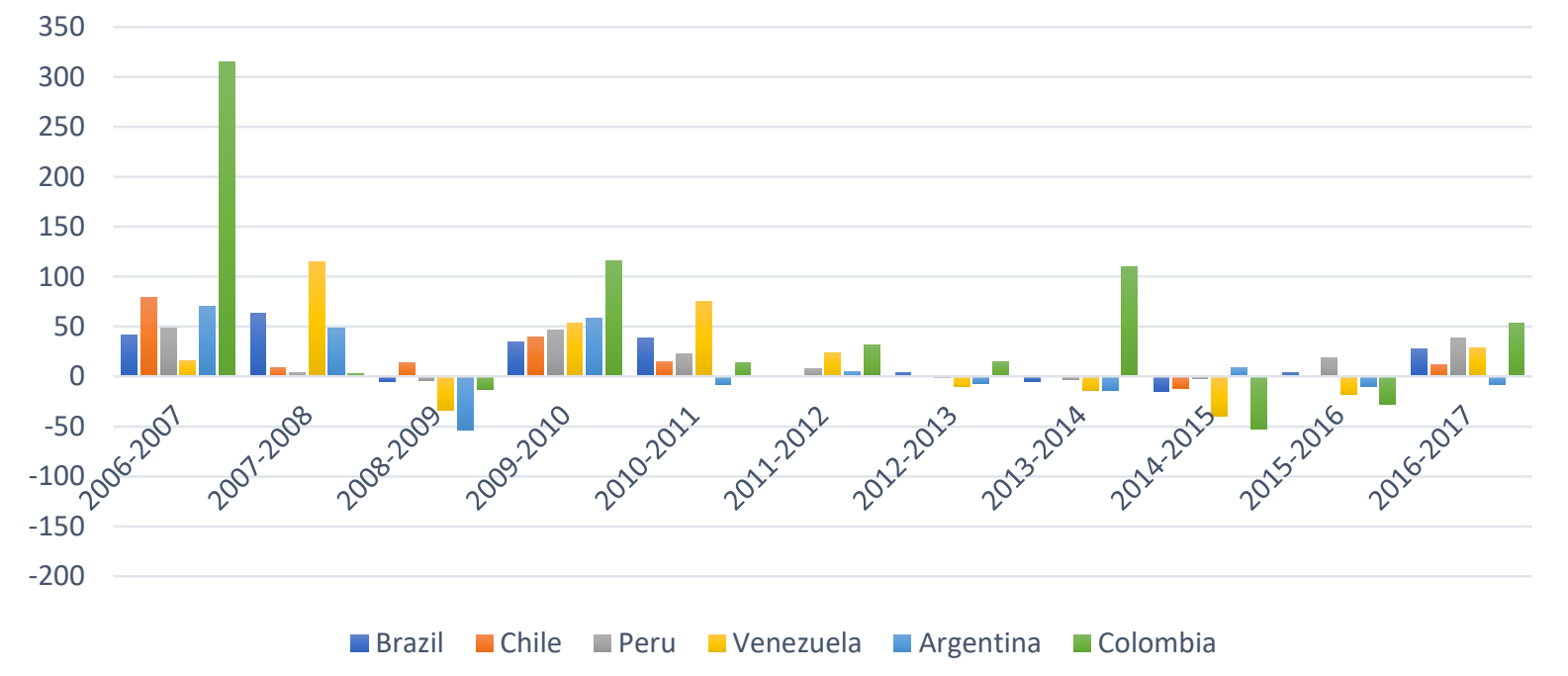

Figure 2 List of supplying markets from Latin America and the Caribbean for a product imported by China

Over the years, China's expenditure on imports has continued to increase at a higher rate than proceeds from exports (UBOS, 2007). During 2006, expenditure on imports amounted to US\$2,557.3 million, which was about US\$ 831,000 more of what was spent in 2004. The continuous expenditure on imports is attributed to the desire to satisfy the domestic market, which has a high demand of 
INTERNATIONAL JOURNAL OF ACADEMIC RESEARCH IN BUSINESS AND SOCIAL SCIENCES Vol. 8, No. 11, Nov, 2018, E-ISSN: 2222-6990 @ 2018 HRMARS

both capital and manufactured goods. For the past decade, petroleum and its products, road vehicles, cereals, iron and steel among others have been the key imports of China. Petroleum products have continued to take the highest expenditure over the years, followed by vehicles and cereals in that order. By 2006, the import expenditure shares for petroleum and its products, road vehicles and cereals were estimated at 20.6, 8.5 and 6.1 percent, respectively.

Table 2 Chinas imports to Latin American Countries (US Dollar Thousands) 2000-2017

\begin{tabular}{lllllll}
\hline years & Brazil & Chile & Peru & Venezuela & Argentina & Colombia \\
\hline 2006 & 12909495 & 5735872 & 2907850 & 2637956 & 3700185 & 263817 \\
2007 & 18342071 & 10280372 & 4337890 & 3052881 & 6334230 & 1095796 \\
2008 & 29863443 & 11172814 & 4492113 & 6567059 & 9361350 & 1125408 \\
2009 & 28280983 & 12790520 & 4323889 & 4340905 & 4306017 & 974821 \\
2010 & 38099447 & 17935193 & 6368186 & 6698878 & 6804128 & 2103363 \\
2011 & 52386750 & 20578293 & 7864277 & 11731210 & 6256572 & 2394851 \\
2012 & 52281127 & 20631633 & 8454698 & 14539106 & 6560806 & 3156664 \\
2013 & 54299123 & 20707685 & 8408062 & 13120097 & 6085768 & 3620271 \\
2014 & 51653225 & 20985876 & 8140872 & 11320054 & 5246944 & 7598890 \\
2015 & 44089358 & 18438962 & 7949920 & 6777714 & 5717476 & 3545141 \\
2016 & 45855047 & 18604964 & 9490808 & 5562819 & 5118096 & 2544629 \\
2017 & 58476878 & 20891275 & 13095544 & 7201764 & 4733007 & 3902252 \\
\hline
\end{tabular}

Other imports include telecommunications, medical and pharmaceutical products. UBOS (2006) asserts that Asia was the largest source of China's imports. China's expenditure on Asian imports between 2005 and 2006 increased by 38.7 percent was attributed to China's entry in the import market. Unlike Asia's increased share of import expenditure, import expenditure share for the African continent significantly reduced from 36.2 percent in 2005 to 25 percent in 2006. Of China's import expenditure on African imports, the Common Market for East and Southern Africa (COMESA) assumed 70.5 percent of the market share. During the past ten years, Kenya has been the major source of imports both on the African continent and COMESA region (62.7 percent and 89 percent respectively). Other African trade partners were Republic of South Africa, Egypt, DRC, to name but a few. 
INTERNATIONAL JOURNAL OF ACADEMIC RESEARCH IN BUSINESS AND SOCIAL SCIENCES Vol. 8, No. 11, Nov, 2018, E-ISSN: 2222-6990 @ 2018 HRMARS

Figure 3 china imports from Latin American Countries (US Dollar thousand) 2000-2017

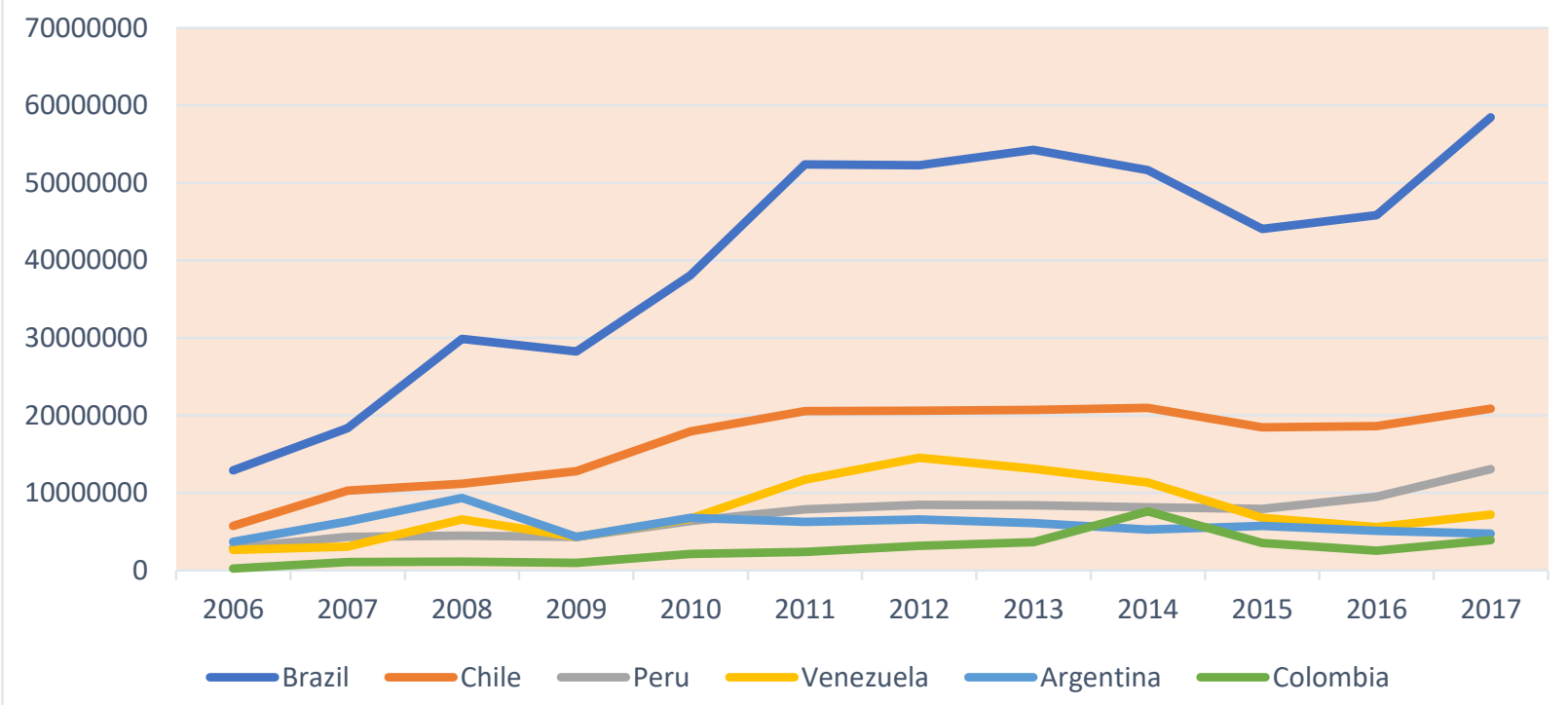

Asia, European Union, North America, and African countries have been the China's leading trading partners over the years. During 2015, Asia's market trade balance was $\$ 185.95$ billion followed by the European Union 110.3 billion, North America 265.1 billion, Latin America 28.4 billion and Africa 38.4 billion. According to the china statistical year book Brazil, Argentina, Mexico, Chile and Peru are the major trading partners among the Latin America States.

Even though trade with China has grown strongly due to the increase in fuel prices and certain basic products, there are still considerable deficiencies. According to CEPAL projects, in 2017 10\% of Latin American merchandise exports to be shipped to China, while $18 \%$ of Latin American imports come from Asian countries. China will exceed the European Union (EU) after the United States as the second biggest buyer of Latin American products, which has by this time lost its position as main exporter to Latin America. Closer focus on the region, especially in the Caribbean, where Mexico and Central America have a large trade deficit with China, while South America's trade balance is almost balanced and the countries with trade surpluses are Chile, Brazil, Venezuela and Peru. This is because the export of raw materials in these countries accounts for $26 \%$ of China's total agricultural imports. In addition to strong export data, the exports are not so encouraging, as trade with China is still basically composed of raw materials for manufactured goods.

\section{Conclusion}

We have developed a framework to measure the Sino-Latin America trade potential and its influencing factors by using gravity theory. Results shows that China's expenditure on imports has continued to increase at a higher rate than proceeds from exports while during 2006, expenditure on imports amounted to US\$2,557.3 million, which was about US\$ 831,000 more of what was spent in 2004. But continuous expenditure on imports is attributed to the desire to satisfy the domestic market, which has a high demand of both capital and manufactured goods during last ten years, petroleum and its products, road vehicles, cereals, iron and steel among others have been the key 
INTERNATIONAL JOURNAL OF ACADEMIC RESEARCH IN BUSINESS AND SOCIAL SCIENCES Vol. 8, No. 11, Nov, 2018, E-ISSN: 2222-6990 @ 2018 HRMARS

imports of China. Petroleum products have continued to take the highest expenditure over the years, followed by vehicles and cereals in that order. Other imports include telecommunications, medical and pharmaceutical products. UBOS (2006) asserts that Asia was the largest source of China's imports. China's expenditure on Asian imports between 2005 and 2006 increased by 38.7 percent was attributed to China's entry in the import market. Unlike Asia's increased share of import expenditure, import expenditure share for the African continent significantly reduced from 36.2 percent in 2005 to 25 percent in 2006. Of China's import expenditure on African imports, the Common Market for East and Southern Africa (COMESA) assumed 70.5 percent of the market share. During the past ten years, Kenya has been the major source of imports both on the African continent and COMESA region (62.7 percent and 89 percent respectively). Other African trade partners were Republic of South Africa, Egypt, DRC, to name but a few.

\section{References}

Alam, M. M., Uddin, G., \& Taufique, K. (2009). Import Inflows of Bangladesh: The Gravity Model Approach.

Allende, A. C. Z. (2016). The Social Impact of the Commercial Trade Between China and Latin America: Toward the Reformulation of Exchanges. In China and Latin America in Transition (pp. 207-226). New York: Palgrave Macmillan US. https://doi.org/10.1057/978-1-137-54080-5_12

Baltagi, B. H., Egger, P. H., \& Pfaffermayr, M. (2014, January). Panel Data Gravity Models of International Trade.

Barton, J. R., \& Rehner, J. (2018). Neostructuralism through strategic transaction: The geopolinomics of China's Dragon Doctrine for Latin America. Political Geography, 65, 77-87. https://doi.org/10.1016/J.POLGEO.2018.05.002

Breslin, S., \& Nesadurai, H. E. S. (2018). Who Governs and How? Non-State Actors and Transnational Governance in Southeast Asia. Journal of Contemporary Asia, 48(2), 187-203. https://doi.org/10.1080/00472336.2017.1416423

Buckley, P. J., Clegg, L. J., Cross, A., Liu, X., Voss, H., \& Zheng, P. (2010). The Determinants of Chinese Outward Foreign Direct Investment. In Foreign Direct Investment, China and the World Economy (pp. 81-118). London: Palgrave Macmillan UK. https://doi.org/10.1057/9780230248328_6

Camarero, M., Gómez-Herrera, E., \& Tamarit, C. (2018). New Evidence on Trade and FDI: how Large is the Euro Effect? Open Economies Review, 29(2), 451-467. https://doi.org/10.1007/s11079018-9479-y

Carrère, C. (2006). Revisiting the effects of regional trade agreements on trade flows with proper specification of the gravity model. European Economic Review, 50(2), 223-247. https://doi.org/10.1016/J.EUROECOREV.2004.06.001

Castro, D. (2018). China Investments in Latin America - A Critical Perspective to the Mainstream Discourse of Imperialism in the Region. SSRN Electronic Journal. https://doi.org/10.2139/ssrn.3211688

Chen, X., Yang, Z., \& Liu, X. (2008). Empirical analysis of Xinjiang's bilateral trade: Gravity model approach. Chinese Geographical Science, 18(1), 9-16. https://doi.org/10.1007/s11769-0080009-5 
INTERNATIONAL JOURNAL OF ACADEMIC RESEARCH IN BUSINESS AND SOCIAL SCIENCES

Vol. 8, No. 11, Nov, 2018, E-ISSN: 2222-6990 @ 2018 HRMARS

Colloredo-Mansfeld, R. (2018). The Rise and Fall of Cheap Chinese Goods in Ecuadorian Popular Markets: The Limits of Post-Neoliberal Development in Correa's Ecuador. The Journal of Latin American and Caribbean Anthropology, 23(1), 37-55. https://doi.org/10.1111/jlca.12289

Dai, M., Maitra, M., \& Yu, M. (2016). Unexceptional exporter performance in China? The role of processing trade. Journal of Development Economics, 121, 177-189. https://doi.org/10.1016/J.JDEVECO.2016.03.007

De Benedictis, L., \& Vicarelli, C. (2005). Trade Potentials in Gravity Panel Data Models. The B.E. Journal of Economic Analysis \& Policy, 5(1). https://doi.org/10.1515/1538-0653.1386

Denoon, D. B. H. (2017). China, $\{$ The $\{$ United $\}$ States $\}$, and the $\{$ Future $\}$ of $\{$ Latin $\}$ America $\}$ : $\{U\} .\{S\} .-\{$ China $\}$ Relations\}.

Eichenauer, V. Z., Fuchs, A., \& Brrckner, L. (2018). The Effects of Trade, Aid, and Investment on China's Image in Developing Countries. SSRN Electronic Journal. https://doi.org/10.2139/ssrn.3147206

Filippini, C., \& Molini, V. (2003). The determinants of East Asian trade flows: a gravity equation approach. Journal of Asian Economics, 14(5), 695-711. https://doi.org/10.1016/J.ASIECO.2003.10.001

Geda, A., \& Kebret, H. (2007). Regional Economic Integration in Africa: A Review of Problems and Prospects with a Case Study of COMESA. Journal of African Economies, 17(3), 357-394. https://doi.org/10.1093/jae/ejm021

Gilboy, G. J. (2016). The Myth Behind China's Miracle. In Seeking Changes (pp. 1-16). Joint Imprint with Central Compilation and Translation Press, China. https://doi.org/10.1142/9789814656306_0001

Hennig, T., \& Harlan, T. (2018). Shades of green energy: Geographies of small hydropower in Yunnan, China and the challenges of over-development. Global Environmental Change, 49, 116-128. https://doi.org/10.1016/J.GLOENVCHA.2017.10.010

K. C. FUNG, A. G.-H. Y.-L. L. (2012). A comparison of Chinese outward direct investment with its regional peers: Japan, South Korea and Taiwan, 238-251. https://doi.org/10.4324/9780203144633-18

Keum, K. (2010). Tourism flows and trade theory: a panel data analysis with the gravity model. The Annals of Regional Science, 44(3), 541-557. https://doi.org/10.1007/s00168-008-0275-2

Kingstone, P. (2018, March). Resources, Production and Structural Dynamics - Google Books. https://doi.org/10.4324/9781315682877

Lee, C. M., \& Kong, H. (2013). GRAVITY MODEL BY PANEL DATA APPROACH: IN WHICH WAY SHOULD SOUTH KOREA (REPUBLIC OF KOREA) TURNS TO THE REGIONAL INTEGRATION, TPP OR ASEAN? A PROJECT SUBMITTED IN PARTIAL FULFILMENT OF THE REQUIREMENTS FOR THE DREGREE OF BACHELOR OF SOCIAL SCIENCES (HONOUR.

Martínez Zarzoz, I., Nowak Lehmann, F., Jaime, U. I., \& Nowak-lehmann, F. (2003). AUGMENTED GRAVITY MODEL: AN EMPIRICAL APPLICATION TO MERCOSUR-EUROPEAN UNION TRADE FLOWS INMACULADA MARTINEZ-ZARZOSO *. AN EMPIRICAL APPLICATION Journal of Applied Economics, $V I(2), 291-316$.

Mohsin, M., Rasheed, A. K., \& Saidur, R. (2018). Economic viability and production capacity of wind generated renewable hydrogen. International Journal of Hydrogen Energy. 
INTERNATIONAL JOURNAL OF ACADEMIC RESEARCH IN BUSINESS AND SOCIAL SCIENCES Vol. 8, No. 11, Nov, 2018, E-ISSN: 2222-6990 @ 2018 HRMARS

https://doi.org/10.1016/j.ijhydene.2017.12.113

Mohsin, M., Zhou, P., Iqbal, N., \& Shah, S. A. A. (2018). Assessing oil supply security of South Asia. Energy, 155, 438-447. https://doi.org/10.1016/J.ENERGY.2018.04.116

Muhammad, A., \& Andrews, D. (2008, April). Determining Tourist Arrivals in Uganda: The Impact of Distance, Trade and Origin-Specific Factors.

Munir, K., \& Javed, Z. (2018). Export composition and economic growth: evidence from South Asian countries. South Asian Journal of Business Studies, 7(2), 225-240. https://doi.org/10.1108/SAJBS-10-2017-0117

Murakami, Y., \& Hernández, R. A. (2018). The impacts of China on economic growth: Evidence for Brazil, Chile, and Peru. Journal of Post Keynesian Economics, 1-25. https://doi.org/10.1080/01603477.2016.1136565

Nguyen, D. P., \& Vo, X. V. (2017). Determinants of bilateral trade: evidence from ASEAN+3. AsianPacific Economic Literature, 31(2), 115-122. https://doi.org/10.1111/apel.12185

Nica, E. (2013). Economics, Management, and Financial Markets. Economics, Management, and Financial Markets (Vol. 8). Denbridge Press.

Ozan Saray, M., Karagoz, K., \& Ozan Saray, M. (2010). Trade Potential of Turkey with Asia-Pacific Countries: Evidence from Panel Gravity Model.

Poncet, S. (2006). Economic Integration of Yunnan with the Greater Mekong Subregion. Asian Economic Journal, 20(3), 303-317. https://doi.org/10.1111/j.1467-8381.2006.00237.x

Porojan, A. (2001). Trade Flows and Spatial Effects: The Gravity Model Revisited. Open Economies Review, 12(3), 265-280. https://doi.org/10.1023/A:1011129422190

Santana-Gallego, M., Ledesma-Rodríguez, F. J., \& Pérez-Rodríguez, J. V. (2016). International trade and tourism flows: An extension of the gravity model. Economic Modelling, 52, 1026-1033. https://doi.org/10.1016/J.ECONMOD.2015.10.043

Schütz, M., \& Palan, N. (2015). Restructuring the International Textile Production and Trade Network. The Role of Italy and Portugal.

Shapiro, D. M., Vecino, C., \& Li, J. (2018). Exploring China's state-led FDI model: Evidence from the extractive sectors in Latin America. Asia Pacific Journal of Management, 35(1), 11-37. https://doi.org/10.1007/s10490-017-9526-z

Teng, C. (2015). Hegemony or Partnership : China's Strategy and Diplomacy Toward Latin America, 84-112. https://doi.org/10.4324/9781315642413-4

Wellmer, F.-W., Buchholz, P., Gutzmer, J., Hagelüken, C., Herzig, P., Littke, R., \& Thauer, R. K. (2019). Current Status of Natural Resources-An Overview. In Raw Materials for Future Energy Supply (pp. 107-144). Cham: Springer International Publishing. https://doi.org/10.1007/978-3-31991229-5_4

Wise, C., Myers, M., \& Myers, M. (2016). Introduction: The Political Economy of China-Latin America Relations in the 21st Century, 9-20. https://doi.org/10.4324/9781315619484-6

WTO. (2015). World Trade Organization International Trade Statistics 2015. the World Trade Organization. https://doi.org/ISBN 978-92-870-3988-0

Yayo, M., \& Asefa, S. (2016). International Trade Effects of Regional Economic Integration In Africa: The Case of the Southern African Development Community (SADC). International Journal of African Development, 3(2). 